\title{
Implementation Strategies for Improving the Teaching Quality of Foreign Language Courses
}

\author{
https://doi.org/10.3991/ijet.v15i24.19031 \\ Zhijiao Li \\ School of Foreign Languages, Jilin, China \\ lzjlydiae126.com
}

\begin{abstract}
The teaching quality of foreign language courses is constrained by various factors. It is no easy task to improve the teaching quality or evaluate it in a reliable manner. To solve the problem, this paper attempts to design feasible strategies for improving the teaching quality of foreign language courses. Firstly, theoretical analysis was carried out on the development of foreign language teaching and the factors affecting the teaching quality, revealing the key obstacles to improving the teaching quality. On this basis, several strategies and paths were put forward to improve the quality of foreign language teaching. In addition, a novel evaluation indicator system and a multiattribute fuzzy evaluation model were established for the teaching quality of foreign language courses. The research results provide strong supports to the teaching optimization of foreign language courses.
\end{abstract}

Keywords-Teaching quality, foreign language courses, implementation strategies, multi-attribute fuzzy evaluation

\section{Introduction}

Teaching quality is an important feature of the teaching level of modern education, and it is also the focus of attention in the implementation process of quality education at present. Since teaching quality plays an important role in modern education, discussion on the improvement of teaching quality and its corresponding internal logic and correlations is of great research significance [1-4]. As an important part of modern education, foreign language teaching has an extremely important catalytic effect on the cultivation of students' comprehensive qualities. Therefore, discussion on the development of foreign language teaching and the improvement of teaching quality has gradually become a research hotspot for educators [5-8]. However, foreign language teaching is restricted by a variety of conditions, resulting in shortcomings in the improvement effects of teaching quality. To solve this problem, many scholars have carried out a series of research and analysis on the improvement of the teaching quality of foreign language courses, and achieved good research results. For example, targeting at the fuzzy problem existing in the evaluation process of the teaching quality of college English courses, CAI proposed a method for evaluating the teaching quality of college English courses based on language phrases and triangular fuzzy 
numbers [9]. WANG built a model for the teaching quality of foreign language based on Analytic Hierarchy Process (AHP), and gave factors affecting the teaching quality of English courses, and this study has a certain guiding significance for the improvement of the teaching quality of English courses [10]. Gore et al. discussed the impact of professional development on teaching quality and provided a reference for the improvement of the teaching quality of foreign language courses [11]. Nithyanandam proposed a framework to improve the quality of teaching and learning processes through the analysis of specific cases, which offers a good guidance for the improvement of the teaching quality of foreign language courses [12]. Wang and Song discussed a fuzzy comprehensive evaluation method of English teaching quality based on the Bat Algorithm, which provided a reference for the fuzzy evaluation and analysis of foreign language teaching quality [13]. However, because the improvement of the teaching quality of foreign language courses is a systematic project, with the continuous development of modern education technologies, the factors affecting the improvement of foreign language teaching quality are constantly changing, and the improvement of the teaching quality of foreign language courses shows more dynamic features. At the same time, although existing research results have certain promotive effects on the improvement of foreign language teaching quality, the different perspectives and starting points of the research make the category of corresponding applications has certain limitations. To this end, this paper further analyzes the problems existing in the processes of the development of foreign language teaching and the improvement of teaching quality, from the perspective of the integration of theoretical analysis and practical application, the paper comprehensively adopts the entropy method [14-15] and the gray theory [16-17] to study the methods and strategies for improving the teaching quality of foreign language courses, as well as the evaluation system and the models.

The research content of this paper consists of 5 parts. The first part gives an overview of relevant research results on the development and improvement of teaching quality in modern education. The second part discusses the constraints of the development of foreign language courses and the improvement of teaching quality. The third part proposes strategies and paths to improve the teaching quality of foreign language courses. The fourth part discusses a multi-attribute fuzzy evaluation model for improving the teaching quality of foreign language courses. The fifth part gives the research conclusions.

\section{Constraints of the Development of Foreign Language Courses and the Improvement of Teaching Quality}

There are many types of foreign language courses, including the widely used English courses, as well as other minority language courses such as German, French, Spanish, and Japanese, etc. Meanwhile, for the courses of each language type, the forms of teaching content are diverse, including the teaching of listening, reading, speaking, and writing, etc. It can be seen that the teaching of foreign language courses of different types and forms is a complex systematic project. In the teaching 
implementation process, it is often restricted by various conditions, which further affect the teaching quality of foreign language courses. In this paper, multiple analysis methods such as literature review, questionnaire survey, expert interview and statistical analysis were adopted to conduct a preliminary analysis on constraints that may affect the development of foreign language courses and the improvement of teaching quality, in summary, they are mainly reflected in the following aspects:

\subsection{Outdated teaching mode of foreign language courses}

As a language learning method, the teaching of various forms of foreign language courses should pay more attention to the quality education of students. Through the comprehensive application of various teaching methods and tools, a teaching atmosphere and environment that is more conducive to language teaching can be created, so that students can quickly blend in the foreign language learning atmosphere, and students' enthusiasm and potential for language learning can be stimulated to the greatest extent, and their foreign language listening, reading, speaking and writing abilities could be effectively improved. However, judging from the implementation process of foreign language teaching, current foreign language teaching still focuses on traditional language teaching methods, lacking innovativeness in teaching methods, tools and forms; often, foreign language teachers just repetitively teach language knowledge according to existing teaching models, mechanically explain various knowledge points such as grammar, sentence patterns, and tenses, more attentions have been paid to the exam scores while the teaching process is often ignored. It can be seen that, essentially, the current foreign language teaching model is still the traditional exam-oriented teaching model, and there is still a gap between current education and quality-oriented education, resulting in a disconnection between the requirement of the times and the development of qualityoriented education, making it difficult for the existing foreign language teaching concepts to effectively adapt to the development of the times, and the teaching quality of foreign language can hardly be improved. For this reason, effectively and reasonably applying a variety of teaching methods and intelligent tools to improve current foreign language teaching modes in a targeted manner so that it can adapt to the development of the times will have a positive promotive effect on the teaching quality of foreign language courses.

\subsection{Weak faculty of foreign language courses}

Teachers are the basic guarantee for the improvement of the teaching quality of foreign language courses. A high-quality faculty is conducive to the improvement of the teaching quality of foreign language courses and the cultivation of foreign language professionals. Compared with other science and engineering disciplines and majors, language disciplines and majors are often not the mainstream in the school, and their status in the school is relatively low. In the construction process of school majors and disciplines, the emphasis on language majors is usually insufficient, and schools generally have limited investment in foreign language courses, therefore the 
construction of faculty is difficult to carry out effectively. Insufficient investment in faculty construction makes it difficult for the software and hardware conditions of foreign language teaching to keep up with the requirements of the development of foreign language teaching, in particular, intelligent education technologies cannot be applied to construct advanced foreign language teaching infrastructure, such as multifunctional language teaching laboratories, multimedia classrooms, key language teaching and research offices, and modern computer centers, etc., and these facilities can provide a solid guarantee for the smooth implementation of foreign language teaching. The inability to carry out faculty construction effectively makes it impossible to introduce high-level professionals in foreign language teaching, meanwhile it has an impact on the training of professional teachers, then it'll be difficult for them to enhance their professional skills, which would result in a low faculty level of foreign language teaching, greatly affecting the teaching ability of teachers and the teaching quality of foreign language courses. Therefore, effectively improving the faculty level of foreign language teaching and building a high-quality faculty for foreign language major will play an indispensable role in promoting the teaching quality of foreign language courses.

\subsection{Inadequate ability to reform and innovate foreign language courses}

Teaching reform and innovation is a trend in the development of modern education, and it is also an important feature of modern education to be able to adapt to the social development. Especially with the rapid development of modern society, the demand for teaching reform and innovation of modern education is becoming more and more urgent. As an important part of modern education, the teaching of foreign language courses also has a problem with teaching reform and innovation, which is reflected in a few aspects such as the teaching content of foreign language courses, the teaching management system of foreign language courses, the curriculum planning of foreign language courses, and the evaluation mechanism of foreign language courses. In terms of the reform and innovation of teaching concept of foreign language courses, through the analysis of the implementation of foreign language teaching, it can be seen that for the foreign language teaching in some schools, the teaching materials, syllabus, teaching plans, training objectives and teaching tasks haven't changed a bit in many years; obviously, under this situation, such teaching concept can hardly meet the requirements of modern education, and the cultivated foreign language professionals can hardly adapt to the requirements of modern society, which means that foreign language professionals cultivated by such teaching concept are not competitive. In terms of the reform and innovation of the teaching management system of foreign language courses, a common problem is the redundant teaching management organization settings, which makes the processing procedure of foreign language teaching affairs extremely complicated, and the implementation process of foreign language teaching tasks and teaching management is fuzzy, the responsibility subjects of foreign language teaching are overlapping, the division of rights, obligations and responsibilities is not clear enough, and all these can affect the quality and efficiency of the teaching management of foreign language 
courses. Obviously, low-level teaching management will directly affect the smooth implementation of foreign language teaching, and it is unable to provide good support for the improvement of the teaching quality of foreign language courses. Moreover, because the reform of foreign language teaching concepts is a systematic project, it cannot be completely transformed overnight; however, the outdated foreign language teaching management system also makes it difficult to implement the improvement of foreign language teaching concepts, thereby forming a vicious circle. In terms of curriculum planning of foreign language teaching, sometimes the current foreign language teaching has the problem that the teaching content of foreign language courses does not match with the student's absorption and acceptance abilities, meaning that there're certain limitations with the logicality, systematicness and hierarchy of the curriculum setting of foreign language courses. In terms of comprehensive application of modern teaching methods, tools and forms, to organically combine the teaching content of foreign language courses with students' cognition, further improvement and discussion are required. In terms of the assessment mechanism of foreign language teaching, the current assessment mechanism has certain problems with the supervision and assessment of the implementation process of foreign language teaching, it's difficult to discover weak links in the teaching process of foreign language courses. Especially, under the condition that the talent cultivation goal and standards of modern foreign language teaching are changing constantly, establishing a good assessment mechanism of foreign language teaching is of important significance. Therefore, effectively promoting the teaching reform of foreign language teaching and enhancing teaching reform and innovation abilities are quite meaningful for improving the teaching quality of foreign language courses.

\subsection{Inadequate ability to integrate professional foreign language abilities}

The teaching of foreign language majors needs to pay attention to the cultivation of students' abilities in listening, speaking, reading, writing and translating; and language learning often involves professional background knowledge of different fields. Therefore, from this perspective, the teaching of foreign language courses requires the integration of professional knowledge, skills and abilities of multiple aspects. However, it can be seen from the implementation process of current foreign language teaching that there are still some limitations in the ability to integrate the professional foreign language abilities, which are mainly reflected in the following aspects: first, the integration of theoretical knowledge and actual practice of foreign language teaching is insufficient, current foreign language teaching mostly focuses on the teaching of basic concepts and theoretical knowledge, while less emphasis has been laid on practical exercises, which makes it difficult to effectively practice and verify the theoretical knowledge, and theoretical knowledge that hasn't been verified in practice is not conductive to students' absorption and learning, and its comprehensive improvement effect on students' language abilities is not very obvious. Second, the integration of industry-university-research of foreign language teaching is insufficient; from the perspective of the development level of modern 
society, modern education, social industries and scientific research are closely interrelated, mutually supportive and mutually promotive. However, the current foreign language teaching focuses more on the courses, ignoring the integration of the three, thereby weakening the promotive effect of the integration of the three on the development of foreign language teaching. Third, the integration of foreign language teaching and social service is insufficient, as an important part of quality education, the ultimate goal of foreign language learning is to serve the society, contribute to the society, and adapt to the requirements of social development. However, usually, modern foreign language teaching only considers the exam scores or certificates, while ignoring the communication and social service features of foreign language learning. Therefore, enhancing the integration of professional foreign language abilities can provide a new solution to the improvement of the teaching quality of foreign language courses.

\section{Strategies and Ways to Improve the Teaching Quality of Foreign Language Courses}

Due to the constraints and limitations of various conditions, the improvement of the teaching quality of foreign language courses requires to comprehensively consider these influencing factors, and take targeted, scientific, and reasonable measures and strategies for the corresponding influencing factors. This study holds that works can be carried out from the following aspects:

\subsection{Increase basic investment in foreign language teaching}

The basic investment in foreign language teaching is an important guarantee for the smooth implementation of foreign language teaching and an important supporting condition for improving the teaching quality of foreign language courses. Increasing the basic investment in foreign language teaching can be carried out from two aspects: one is to increase investment in the construction of foreign language majors and disciplines, and provide more financial support for the implementation of foreign language teaching; the other is to improve the software and hardware environment of foreign language teaching, build various facilities such as multi-functional language laboratories, teaching and research offices, multimedia classrooms, intelligent teaching platforms, and intelligent teaching management systems, etc., and provide a solid hardware support for the implementation of foreign language teaching.

\subsection{Enhance the teaching ability and level of the faculty of foreign language majors}

The teaching ability and level of the faculty of foreign language majors is the basic condition for the smooth implementation of foreign language teaching, and it is also the most direct factor to improve the teaching quality of foreign language courses. Enhancing the teaching ability and level of the faculty of foreign language majors can 
be carried out from three aspects: the first is to introduce high-level foreign language professionals with senior professional titles and high academic qualifications, so as to supplement the teaching force by introducing senior talents; the second is to cultivate young faculty for foreign language teaching so that they can grow and become senior talents with high-level professional abilities, thereby achieving the optimization of the faculty team of foreign language teaching; the third is to enhance the training and academic exchanges of foreign language teachers, and improve the comprehensive professional abilities and teaching level of foreign language teachers.

\subsection{Improve the reform and innovation ability of foreign language teaching}

The reform and innovation ability of foreign language teaching is the driving force for the development of foreign language teaching, and it is also the catalyst for improving the teaching quality of foreign language courses. Improving the reform and innovation ability of foreign language teaching can be carried out from three aspects: The first is to encourage foreign language teachers to undertake or participate in more projects that are related to teaching reform of foreign language courses, so as to enhance their ability in teaching reform through the implementation of teaching reform programs. The second is to plan the foreign language courses combining with the characteristics of the times, and construct a curriculum system with the features of foreign language majors. The third is to encourage foreign language teachers to participate in the construction of foreign language majors, so as to enhance their teaching reform awareness and ability by promoting the development of foreign language majors.

\subsection{Improve the management system and mechanism of foreign language teaching}

The management system and mechanism of foreign language teaching has strong directional and instructional features for the implementation of foreign language teaching, a good management system and mechanism of foreign language teaching is more conducive to the implementation of foreign language teaching and the improvement of teaching quality of foreign language courses. Improving the management system and mechanism of foreign language teaching needs to be carried out from three aspects: namely do a good job in formulating rules and regulations of foreign language teaching management; do a good job in formulating rules and regulations of foreign language teaching assessment; and do a good job in formulating rules and regulations of foreign language student management. 


\section{Multi-Attribute Fuzzy Evaluation Model for Improving the Teaching Quality of Foreign Language Courses}

Under above-mentioned measures and strategies, to effectively measure the improvement of the teaching quality of foreign language courses, a corresponding multi-attribute fuzzy evaluation model needs to be established.

\subsection{Principles for selecting evaluation indicators}

The selection of evaluation indicators directly affects the scientificity and reliability of the evaluation of the teaching quality of foreign language courses, therefore, this paper holds that the selection of evaluation indicators should follow certain principles.

Scientific principle: The evaluation indicators must have specific scientific meanings, which can reflect the connotation and essential characteristics of the evaluation of teaching quality of foreign language courses.

Objective principle: The evaluation indicators should be selected based on objective facts, not on individual subjective choices, they should be able to reflect the objective evaluation information of the teaching quality of foreign language courses.

Overall principle: The evaluation indicators should be able to achieve the evaluation of the teaching quality of foreign language courses from an overall perspective, the evaluation should not be limited to partial links.

Hierarchical principle: The evaluation indicators should have a hierarchical structure, and the constructed evaluation indicator system should have very clear hierarchical relationships.

Independent principle: The selection of evaluation indicators should avoid information redundancy as much as possible, so that the evaluation structure of the teaching quality of foreign language courses could be more accurate.

Quantified principle: The evaluation indicators should be able to obtain numerical values for the evaluation, so that the evaluation process of the teaching quality of foreign language courses can be quantified and analysed more easily. 


\subsection{Construction of evaluation indicator system}

Table 1. Evaluation indicator system for the teaching quality of foreign language courses

\begin{tabular}{|c|c|c|}
\hline Indicator system & First-level indicator & Second-level indicator \\
\hline \multirow{33}{*}{$\begin{array}{l}\text { Evaluation indicator system } \\
\text { for the teaching quality of } \\
\text { foreign language courses }\end{array}$} & \multirow{9}{*}{$\begin{array}{l}\text { Ability to guarantee } \\
\text { foreign language } \\
\text { teaching }\end{array}$} & Financial input in teaching \\
\hline & & Faculty construction level \\
\hline & & Ability to form talent team \\
\hline & & Software and hardware teaching facilities \\
\hline & & Professional qualities of teachers \\
\hline & & Rationality of rules and regulations \\
\hline & & Rationality of organization setting \\
\hline & & Teaching reform ability \\
\hline & & Teaching integration ability \\
\hline & \multirow{12}{*}{$\begin{array}{l}\text { Ability to carry out } \\
\text { foreign language } \\
\text { teaching }\end{array}$} & Accurate teaching goals \\
\hline & & Suited syllabus \\
\hline & & Scientific teaching scheme \\
\hline & & Intelligent teaching tools \\
\hline & & Advanced teaching methods \\
\hline & & Rich teaching content \\
\hline & & Diverse teaching forms \\
\hline & & Reasonable curriculum planning \\
\hline & & Atmosphere and environment of classroom teaching \\
\hline & & Timely interaction after class \\
\hline & & Comprehensive teaching assessment \\
\hline & & Correct teaching attitude \\
\hline & \multirow{12}{*}{$\begin{array}{l}\text { Implementation effect } \\
\text { of foreign language } \\
\text { teaching }\end{array}$} & Pass rate of students \\
\hline & & Excellent rate of students \\
\hline & & Autonomous learning ability of students \\
\hline & & Innovation ability of students \\
\hline & & Social service ability \\
\hline & & Practical application ability \\
\hline & & Number of awards from student competitions \\
\hline & & Number of teaching reform programs undertaken \\
\hline & & $\begin{array}{l}\text { Number of excellent teaching material and courses } \\
\text { compiled }\end{array}$ \\
\hline & & Number of teaching reform papers published \\
\hline & & Number of teaching awards received by teachers \\
\hline & & Completion of teaching tasks \\
\hline
\end{tabular}

Following the above-mentioned principles, this paper constructed an evaluation indicator system for the teaching quality of foreign language courses from three aspects of the ability to guarantee foreign language teaching, the ability to carry out foreign language teaching, and the implementation effect of foreign language teaching, the specific content is shown in Table 1. 


\subsection{Standardization of evaluation indicators}

It can be seen from the above-established indicator system for the evaluation of teaching quality of foreign language courses that, the evaluation indicators have diverse types and different measurement standards, therefore, to make the evaluation results reliable, all evaluation indicators should have a same measurement standard. In this paper, it's assumed that there're $\mathrm{n}$ evaluation indicators, then the initial value of evaluation object $Q$ with respect to evaluation indicator $j$ is $V_{j}(Q)$, and the value range of evaluation indicator $j$ is $\left[V_{j}\left(\min ()_{j}(\max ())\right)\right], V_{j}\left(\min ()_{j}(\max ())\right), 1 \leq j \leq n$.

If evaluation indicator $j$ is a positive indicator, that is, the larger the value, the better, then the standardized value of evaluation object $Q$ with respect to evaluation indicator $j$ is $U_{j}(Q)$, namely:

$$
U_{j}(Q)=\frac{V_{j}(Q)-V_{j}(\min )}{V_{j}(\max )-V_{j}(\min )}
$$

If evaluation indicator $j$ is a negative indicator, that is, the smaller the value, the better, then the standardized value of evaluation object $Q$ with respect to evaluation indicator $j$ is $U_{j}(Q)$, namely:

$$
U_{j}(Q)=\frac{V_{j}(\max )-V_{j}(Q)}{V_{j}(\max )-V_{j}(\min )}
$$

It can be seen that after the standardization process, the value of the evaluation indicator $j$ of evaluation object $Q$ is a standardized value, and all the evaluation indicators have a unified measurement standard and they satisfy $0 \leq U_{j}(Q) \leq 1$.

\subsection{Obtaining the weights of evaluation indicators}

According to information theory, entropy can reflect the stability of a complex system based on the amount of information of system indicators. A stable complex system contains less information, and its corresponding entropy value is smaller, which means that the indicators have a smaller impact on the system [18-20]. Therefore, based on this principle, the indicator entropy values can be calculated based on the acquired evaluation indicators, the degree of dispersion of the evaluation indicator system can be analysed, thereby the weights of different evaluation indicators could be obtained.

Suppose there are a total of $m$ evaluation objects, and the standardized value of evaluation indicator $j$ of the $i$-th evaluation object is $U_{i j}(Q)$, then the entropy value $H_{j}$ of evaluation indicator $j$ is:

$$
H_{j}=-\frac{1}{\ln m} \sum_{i=1}^{m}\left(\left(U_{i j}(Q) / \sum_{i=1}^{m} U_{i j}(Q)\right) * \ln \left(U_{i j}(Q) / \sum_{i=1}^{m} U_{i j}(Q)\right)\right)
$$


And there is:

$$
\lim _{\left(U_{i j}(Q) / \sum_{i=1}^{m} U_{i j}(Q)\right) \rightarrow 0}\left(\left(U_{i j}(Q) / \sum_{i=1}^{m} U_{i j}(Q)\right) * \ln \left(U_{i j}(Q) / \sum_{i=1}^{m} U_{i j}(Q)\right)\right)=0
$$

Thus, the weight $w_{j}$ of evaluation indicator $j$ is:

$$
w_{j}=\left(1-H_{j}\right) / \sum_{j=1}^{n}\left(1-H_{j}\right)
$$

The corresponding weight sequence $W$ of the evaluation indicators is:

$$
W=\left\{w_{1}, w_{2}, \cdots, w_{j}, \cdots w_{n-1}, w_{n}\right\}, \quad 1 \leq j \leq n
$$

\subsection{Construction of evaluation model}

By seeking the opinions of experts in the field and combining the actual needs of the evaluation of the teaching quality of foreign language courses, this paper divided the teaching quality levels of foreign language courses into five degrees: excellent, good, average, qualified, and unqualified. Based on the gray clustering analysis method, gray clustering functions of the five degrees can be established separately [21-24].

The excellent teaching quality level is marked as LEVI, the corresponding gray clustering function $f_{L E V 1}\left(U_{j}(Q)\right)$ is shown in Figure 1.

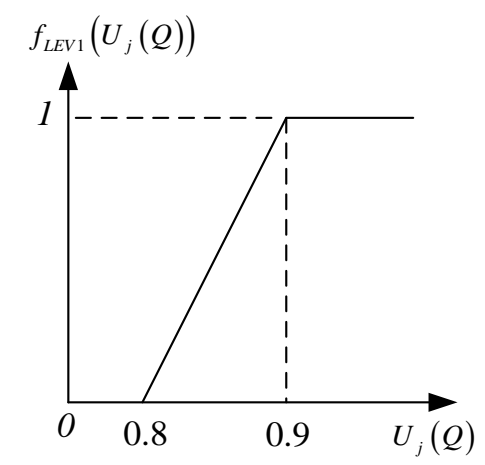

Fig. 1. Grey clustering function $f_{L E V 1}\left(U_{j}(Q)\right)$

Then the corresponding calculation model of $f_{L E V 1}\left(U_{j}(Q)\right)$ is: 


$$
f_{L E V 1}\left(U_{j}(Q)\right)\left\{\begin{array}{lc}
1 & U_{j}(Q) \geq 0.9 \\
\frac{U_{j}(Q)-0.8}{0.1} & 0.8 \leq U_{j}(Q) \leq 0.9 \\
0 & u_{i j} \leq 0.8
\end{array}\right.
$$

The good teaching quality level is marked as $L E V 2$, the corresponding gray clustering function $f_{L E V 2}\left(U_{j}(Q)\right)$ is shown in Figure 2.

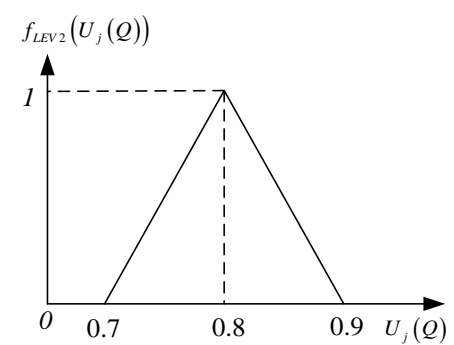

Fig. 2. Grey clustering function $f_{L E V 2}\left(U_{j}(Q)\right)$

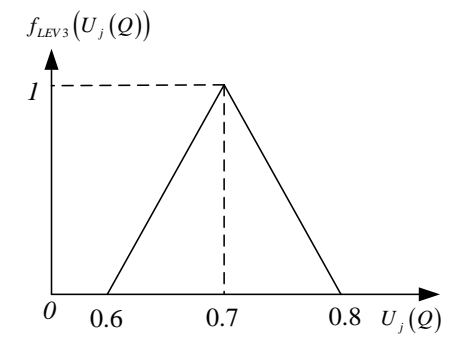

Fig. 3. Grey clustering function $f_{L E V 3}\left(U_{j}(Q)\right)$

Then the corresponding calculation model of $f_{L E V 2}\left(U_{j}(Q)\right)$ is:

$$
f_{L E V 2}\left(U_{j}(Q)\right)=\left\{\begin{array}{lc}
0 & U_{j}(Q) \leq 0.7 \text { or } U_{j}(Q) \geq 0.9 \\
\frac{U_{j}(Q)-0.7}{0.1} & 0.7 \leq U_{j}(Q) \leq 0.8 \\
\frac{0.9-U_{j}(Q)}{0.1} & 0.8 \leq U_{j}(Q) \leq 0.9
\end{array}\right.
$$

The average teaching quality level is marked as LEV3, the corresponding gray clustering function $f_{L E V 3}\left(U_{j}(Q)\right)$ is shown in Figure 3.

Then the corresponding calculation model of $f_{L E V 3}\left(U_{j}(Q)\right)$ is: 


$$
f_{L E V 3}\left(U_{j}(Q)\right)=\left\{\begin{array}{lc}
0 & U_{j}(Q) \leq 0.6 \text { or } U_{j}(Q) \geq 0.8 \\
\frac{U_{j}(Q)-0.6}{0.1} & 0.6 \leq U_{j}(Q) \leq 0.7 \\
\frac{0.8-U_{j}(Q)}{0.1} & 0.7 \leq U_{j}(Q) \leq 0.8
\end{array}\right.
$$

The qualified teaching quality level is marked as LEV4, the corresponding gray clustering function $f_{L E V 4}\left(U_{j}(Q)\right)$ is shown in Figure 4.

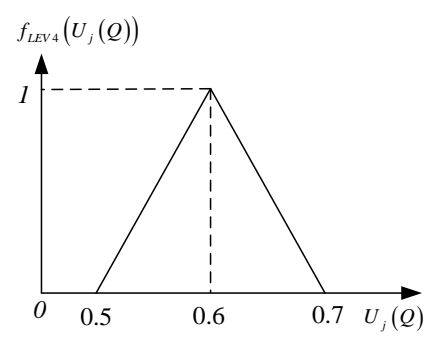

Fig. 4. Grey clustering function $f_{L E V 4}\left(U_{j}(Q)\right)$

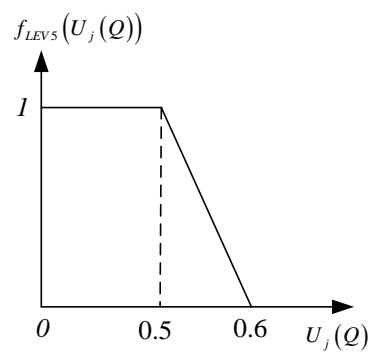

Fig. 5. Grey clustering function $f_{L E V 5}\left(U_{j}(Q)\right)$

Then the corresponding calculation model of $f_{L E V 4}\left(U_{j}(Q)\right)$ is:

$$
f_{L E V 4}\left(U_{j}(Q)\right)=\left\{\begin{array}{lc}
0 & U_{j}(Q) \leq 0.5 \text { or } U_{j}(Q) \geq 0.7 \\
\frac{U_{j}(Q)-0.5}{0.1} & 0.5 \leq U_{j}(Q) \leq 0.6 \\
\frac{0.7-U_{j}(Q)}{0.1} & 0.6 \leq U_{j}(Q) \leq 0.7
\end{array}\right.
$$

The unqualified teaching quality level is marked as LEV5, the corresponding gray clustering function $f_{L E V 5}\left(U_{j}(Q)\right)$ is shown in Figure 5 .

Then the corresponding calculation model of $f_{L E V 5}\left(U_{j}(Q)\right)$ is: 


$$
f_{L E V 5}\left(U_{j}(Q)\right)=\left\{\begin{array}{lr}
0 & U_{j}(Q) \geq 0.6 \\
\frac{0.6-U_{j}(Q)}{0.1} & 0.5 \leq U_{j}(Q) \leq 0.6 \\
1 & 0 \leq U_{j}(Q) \leq 0.5
\end{array}\right.
$$

Therefore, based on the above calculation models, the gray correlation coefficient $f_{L E V k}\left(U_{i j}(Q)\right)$ of the $i$-th evaluation object with respect to evaluation indicator $j$ and the $k$-th evaluation degree could be obtained; at the same time, considering the weights of different evaluation indicators, the gray correlation degree $\varphi_{L E V k}\left(U_{i}(Q)\right)$ between the $i$-th evaluation object and the $k$-th evaluation degree can be obtained, namely:

$$
\varphi_{\text {LEVk }}\left(U_{i}(Q)\right)=\sum_{j=1}^{n}\left(w_{j} * f_{L E V k}\left(U_{i j}(Q)\right)\right), 1 \leq k \leq 5
$$

If it satisfies:

$$
\varphi_{L E V l}\left(U_{i}(Q)\right)=\max _{1 \leq k \leq 5}\left(\varphi_{L E V k}\left(U_{i}(Q)\right)\right), 1 \leq l, k \leq 5
$$

It means that, for the current evaluation object $i$, its teaching quality of foreign language courses is evaluated to be the $l$-th degree.

\section{Conclusion}

The research work of this paper had achieved some results in the following three aspects: first, it analysed the relevant factors restricting the development of foreign language teaching and the improvement of teaching quality, and discussed the internal reasons that affect the improvement of foreign language teaching quality; second, the paper explored strategies and ways to improve the teaching quality of foreign language courses, and provided a good support for effectively improving the teaching quality of foreign language courses; third, the paper proposed an improved evaluation indicator system of foreign language teaching, and constructed a multi-attribute fuzzy evaluation model for improving the teaching quality of foreign language courses, thereby achieved quantitative analysis of the teaching quality of foreign language courses, and offered an effective measurement tool for evaluating the teaching quality of foreign language courses, the research of this paper is of important application value.

\section{Acknowledgements}

This work has obtained the funding from "Research on ICC Cultivation of Nonforeign Language Majors from the Perspective of "Third Space Theory" and 
"Research on the Collaborative Path between Foreign Language Courses and Curriculum Ideological and Political Education in Application-oriented Universities".

\section{$7 \quad$ Reference}

[1] Fauth, B., Decristan, J., Decher, A.T., Buttner, G., Hardy, I., Klieme, E., Kunter, M. (2019). The effects of teacher competence on student outcomes in elementary science education: The mediating role of teaching quality. Teaching and Teacher Education, 86: 114. https://doi.org/10.1016/j.tate.2019.102882

[2] Palali, A., Elk, R.V., Bolhaar, J., Rud, I. (2018). Are good researchers also good teachers? The relationship between research quality and teaching quality. Economics of Education Review, 64: 40-49. https://doi.org/10.1016/j.econedurev.2018.03.011

[3] Dong, C.H., Pang, Z.Q., Wu, G.Y. (2020). Problems and Countermeasures in English Learning of Postgraduates. Education Modernization, 7(35): 41-43+46. https://doi.org/ 1 $\underline{0.16541 / j . c n k i .2095-8420.2020 .35 .012}$

[4] Yang, F. (2019). Research on the orientation of English major training in physical education institutions from the perspective of national standard--a case study of Nanjing Sport Institute. Education Modernization, 6(35): 21-23. https://doi.org/10.16541/j.cnki.209 $\underline{5-8420.2019 .35 .008}$

[5] Yu, F. (2018). The analysis of the way of realizing high quality English teaching in college in the era of big data. Journal of Guiyang University Social Science, 13(1): 89-91. https://doi.org/10.16856/j.cnki.52-1141/c.2018.01.019.

[6] Huang, N. (2020). Exploration on the Teaching Mode of Integrating Scientific Research and Teaching in College English Course. Journal of Tianjin Sino-German University of Applied Sciences, (3): 92-95. https://doi.org/10.16350/j.cnki.cn12-1442/g4.2020.03.022

[7] Zhang, J.S. (2020). Evaluation of English Teaching Quality Based on GA Optimized RBF Neural Network. Computer Systems \& Applications, 29(3): 167-172. http://dx.doi.org/ 10.15888/j.cnki.csa.007302.

[8] Zhou, Q.Q. (2017). Research on the construction of multimodal English teaching mode in Higher Vocational Colleges in the information age. Journal of Suzhou Education Institute, 20(6): 140-141. https://doi.org/10.13985/j.cnki.34-1227/c.2017.06.065 .

[9] Cai, Q. (2019). Evaluation on Teaching Quality of College English based on Triangular Fuzzy Numbers. Journal of Guizhou Education University, 35(1): 67-71. https://doi.org/ 10.13391/j.cnki.issn.1674-7798.2019.01.013.

[10] Wang, Y.X. (2017). Analysis of the Factors Influencing the Quality of Junior High School English Teaching based on Analytic Hierarchy Process. Education Modernization, 4(49): 388-390. https://doi.org/10.16541/j.cnki.2095-8420.2017.49.134.

[11] Gore, J., Lloyd, A., Smith, M., Bowe, J., Ellis, H., Kubans, D. (2017). Effects of professional development on the quality of teaching: Results from a randomised controlled trial of Quality Teaching Rounds. Teaching and Teacher Education, 68: 99-113. https:// doi.org/10.1016/j.tate.2017.08.007.

[12] Nithyanandam, G.K. (2020). Research on the implementation effect of micro class teaching in the teaching process of art courses in Higher Vocational Colleges. Procedia Computer Science, 172: 92-97. http://dx.doi.org/10.1016/j.procs.2020.05.013

[13] Wang, S.Q., Song, R. (2020). Evaluation of English teaching quality based on fuzzy comprehensive evaluation and bat algorithm. Information Technology, 4: 102-106. http://dx.doi.org/10.13274/j.cnki.hdzj.2020.04.022 
[14] Ouchtati, S., Chergui, A., Mavromatis, S., Aissa, B., Rafik, D., Sequeira J. (2019). Novel method for brain tumor classification based on use of image entropy and seven Hu's invariant moments. Traitement du Signal, 36(6): 483-491. https://doi.org/10.18280/ts. $\underline{360602}$

[15] Murugan, S., Kulanthaivel, G., Ulagamuthalvi, V. (2019). Selection of test case features using fuzzy entropy measure and random forest. Ingénierie des Systèmes d'Information, 24(3): 261-268. https://doi.org/10.18280/isi.240306

[16] Delgado, A., Romero, I. (2016). Environmental conflict analysis using an integrated grey clustering and entropy-weight method: A case study of a mining project in Peru. Environmental Modelling \& Software, 77: 108-121. https://doi.org/10.1016/j.envsoft.2015. $\underline{12.011 .}$.

[17] Song, S.L. (2018). Application of gray prediction and linear programming model in economic management. Mathematical Modelling of Engineering Problems, 5(1): 46-50. https://doi.org/10.18280/mmep.050107

[18] Zhou, M.L., Liu, Y., Sun, G.X., Bin, S. (2018). A novel public opinion detection algorithm based on complex network. Revue d'Intelligence Artificielle, 32(S1): 125-134. https://doi. org/10.3166/RIA.32.S1.125-134

[19] Xing, R.F., Fan, Y.Y., Liu, W. (2019). A Markov chain-based overlapping community detection algorithm for complex networks. Ingénierie des Systèmes d'Information, 24(6): 577-582. https://doi.org/10.18280/isi.240603

[20] Xiu, G.Y., Yuan, C.Y., Chen, X.H., Li, X.S. (2019). An innovative beam hardening correction method for computed tomography systems. Traitement du Signal, 36(6): 515520. https://doi.org/10.18280/ts.360606

[21] Tuncer, S.A., Alkan, A. (2019). Spinal cord-based kidney segmentation using connected component labeling and K-means clustering algorithm. Traitement du Signal, 36(6): 521527. https://doi.org/10.18280/ts.360607

[22] Guo, Q., Zou, G.T., Sun, T.Z. (2018). Discovery of the knowledge on the demands of building users based on extension clustering. Revue d'Intelligence Artificielle, 32(5-6), 705-718. https://doi.org/10.3166/ria.32.705-718

[23] Jiao, Q.J., Jin, Y.Y. (2019). Selection of significant community structure based on network partition-based cluster. Journal Européen des Systèmes Automatisés, 52(1): 35-41. https:// doi.org/10.18280/jesa.520105

[24] Zhang, C., Pan, S., Qi, Y.W., Yang, Y.D. (2019). A footprint extraction and recognition algorithm based on plantar pressure. Traitement du Signal, 36(5): 419-424. https://doi.org/ $\underline{10.18280 / \text { ts. } 360506}$

\section{Author}

Zhijiao Li, female, native of Jilin City, Jilin Province, Master, lecturer. She received her Bachelor of Arts Degree in English from Jilin Normal University in 2009 and Master of Arts Degree in Foreign Linguistics and Applied Linguistics from Yanbian University in 2012. Now she works in the Foreign Language School of Jilin University of Chemical Technology, teaching college English courses for more than 8 years. Her research interests include applied linguistics and cross-cultural communication, and she has published more than 10 related papers. She has presided over one university-level scientific research project, participated in two social science fund projects of Jilin Province, one scientific research planning project of The 
Education Department of Jilin Province, one teaching and research project of the 13th Five-Year Plan of Education Science of Jilin Province, one project of Jilin Social Science Union, and one project of Jilin City Social Science Union. In 2019, She won the second prize of provincial level in the "Teaching Star" competition of Foreign Research Press, and guided students to complete one national innovation and entrepreneurship project for college students.

Article submitted 2020-10-03. Resubmitted 2020-11-17. Final acceptance 2020-11-18. Final version published as submitted by the authors. 